Please cite this paper as:

Robin-Olivier, S. (2016), "The Community Preference Principle in Labour Migration Policy in the European Union", OECD Social, Employment and Migration Working Papers, No. 182, OECD Publishing, Paris. http://dx.doi.org/10.1787/5jlwxbzcfsq6-en

OECD Social, Employment and Migration Working Papers No. 182

\title{
The Community Preference Principle in Labour Migration Policy in the European Union
}

Sophie Robin-Olivier

JEL Classification: F22, K31, K37, N44 
Organisation de Coopération et de Développement Économiques

Organisation for Economic Co-operation and Development

27-May-2016

DIRECTORATE FOR EMPLOYMENT, LABOUR AND SOCIAL AFFAIRS

English - Or. English

EMPLOYMENT, LABOUR AND SOCIAL AFFAIRS COMMITTEE

Cancels \& replaces the same document of 04 May 2016

The Community Preference Principle in Labour Migration Policy in the European Union

Sophie Robin-Olivier (University of Paris 1)

JEL Classification: F22, K37, K31, N44

This paper is part of the joint project between the Directorate General for Migration and Home Affairs of the European Commission and the OECD's Directorate for Employment, Labour and Social Affairs on "Review of Labour Migration Policy in Europe".

This document has been produced with the financial assistance of the European Union. The views expressed herein can in no way be taken to reflect the official opinion of the European Union.

Grant: HOME/2013/EIFX/CA/002 / 30-CE-0615920/00-38 (DI130895)

A previous version of this paper was presented and discussed at the OECD Working Party on Migration in June 2015.

Authorised for publication by Stefano Scarpetta, Director, Directorate for Employment, Labour and Social Affairs.

www.oecd.org/els/workingpapers

JT03396818

Complete document available on OLIS in its original format

This document and any map included herein are without prejudice to the status of or sovereignty over any territory, to the delimitation of international frontiers and boundaries and to the name of any territory, city or area. 


\title{
DIRECTORATE FOR EMPLOYMENT, LABOUR AND SOCIAL AFFAIRS
}

\author{
www.oecd.org/els
}

\section{OECD SOCIAL, EMPLOYMENT AND MIGRATION WORKING PAPERS}

\author{
www.oecd.org/els/workingpapers
}

OECD Working Papers should not be reported as representing the official views of the OECD nor of its member countries nor of the members of the European Union. The opinions expressed and arguments employed are those of the author(s).

Working Papers describe preliminary results or research in progress by the author(s) and are published to stimulate discussion on a broad range of issues on which the OECD works. Comments on Working Papers are welcomed, and may be sent to the Directorate for Employment, Labour and Social Affairs OECD, 2 rue André-Pascal, 75775 Paris Cedex 16, France.

This series is designed to make available to a wider readership selected labour market, social policy and migration studies prepared for use within the OECD. Authorship is usually collective, but principal writers are named. The papers are generally available only in their original language - English or French with a summary in the other.

This document and any map included herein are without prejudice to the status of or sovereignty over any territory, to the delimitation of international frontiers and boundaries and to the name of any territory, city or area.

\section{Applications for permission to reproduce or translate all or part of this material should be made to:}

\author{
Head of Publications Service \\ OECD \\ 2, rue André-Pascal \\ 75775 Paris, CEDEX 16 \\ France
}

Copyright OECD 2016 


\begin{abstract}
This paper is part of the joint project between the Directorate General for Migration and Home Affairs of the European Commission and the OECD's Directorate for Employment, Labour and Social Affairs on "Review of Labour Migration Policy in Europe".

This document has been produced with the financial assistance of the European Union. The views expressed herein can in no way be taken to reflect the official opinion of the European Union.

Grant: HOME/2013/EIFX/CA/002 / 30-CE-0615920/00-38 (DI130895)

A previous version of this paper was presented and discussed at the OECD Working Party on Migration in June 2015.The paper investigates the notion of the "community preference" which in filling job posts gives a priority to EU-nationals over third-country nationals. Analysing the impact of the principle on the European labour migration policy, the report presents a brief history of the notion, and discusses how it is referred to in EU labour migration policy documents. It also examines the challenges that the principle is facing as the EU immigration policy develops, tending to give increasing rights to third-country nationals.
\end{abstract}




\section{TABLE OF CONTENTS}

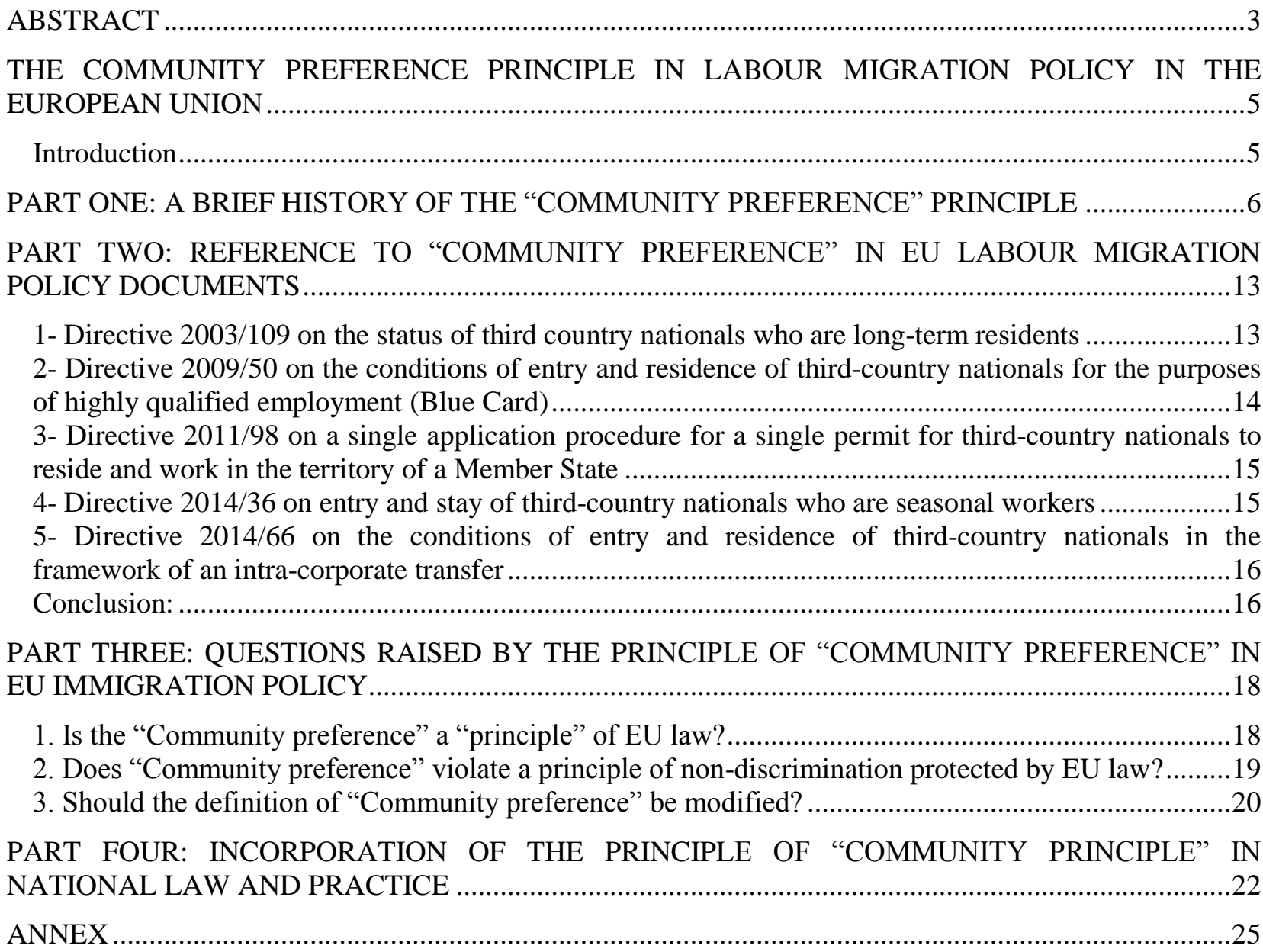

\section{Tables}

Table 1. APPLICABILITY OF COMMUNITY PREFERENCE TO PERMIT CATEGORIES COVERED BY EU DIRECTIVES 
DELSA/ELSA/WD/SEM(2016)8

\section{THE COMMUNITY PREFERENCE PRINCIPLE IN LABOUR MIGRATION POLICY IN THE EUROPEAN UNION}

\section{Introduction}

1. "Community preference" can be defined as the requirement within the single labour market of the EU (and EEA+Switzerland) that, in filling posts, employers are required to give preference to EU nationals over third-country nationals. This notion of "Community preference" was never a central one in the development of EU law concerning free movement of workers. But it became more important, in recent times, when accession treaties with new Member States relied on it to ensure, in the absence of a right to free movement being granted to citizens of joining States during transition periods, a priority to these new EU citizens over third-country nationals.

2. Recent developments of EU immigration policy also contributed to the growing attention paid to this notion. As "Community preference" supports free of movement of workers, its extension to thirdcountry nationals, especially those who are residents of a Member State of the EU (and EEA + Switzerland), has been suggested, as a means to ensure mobility of the workforce, within the single market, and ensure a more favourable treatment, based on EU law, to some third-country nationals, who have reached a certain level of integration in the EU.

3. "Community preference", defined as a preference to EU citizens, can be considered a tool to achieve the EU objective of a single (labour) market. However, as EU immigration policy develops, and new instruments intend to increase the rights of third-country nationals within the EU, and on the EU labour market, in particular, the hierarchy between the different categories of workers (nationals, EU citizens and third country nationals) has become more uncertain and a preference to EU citizens may appear less justified. This is true both at EU and national levels.

4. This report concerns the notion and impact of the principle of "Community preference" in labour migration policy in the EU and its Member States. It is considering whether policies concerning the admission of third-country nationals for work purposes, in the EU or in Member States, rely on this principle, and how.

5. In order to support a reflection on the present and future role of the "Community preference", this paper will start with presenting a brief history of the "Community preference" principle, its origins and its extensions to accession countries (e.g., in the Accession Acts of 2003, 2005 and 2012). In a second part, it will consider references to the principle in EU labour migration policy documents. The third part is devoted to the main questions/problems that this principle faces, as the EU immigration policy expands, and tends to give more rights than before to third-country nationals. In its last part, this report considers, as an example, the form through which preference (for nationals and for broader categories, including EU and EEA/EFTA citizens) is ensured in France and how it represents a practical application of the "Community preference"

principle. 


\section{PART ONE: A BRIEF HISTORY OF THE "COMMUNITY PREFERENCE" PRINCIPLE}

6. The notion of "Community preference" was not mentioned in the Rome treaty. When the common market was established, the idea that goods from Member states had to be given preference over imported products from outside the EEC was not ignored: the idea was debated, and rejected ${ }^{1}$. On the contrary, instead of a "Community preference", it was decided, as the sixth recital of the preamble of the Rome treaty indicates, that Member states would contribute to reducing obstacles to international trade through their common commercial policy.

7. The notion of a "Community preference" was introduced, to begin with, in the field of agricultural policy. Although it was not explicitly mentioned in the Rome treaty, article 40 of that treaty indicates that common organisation of agricultural markets must exclude discriminations between producers or consumers of the Community, and article $44 \S 2$ contains a notion very close to "Community preference": it states that minimal prices should not be obstacles to the development of a "natural preference" between Member States.

8. The notion of "Community preference" as such became part of EEC law when it was used by the European Court of Justice in a decision of $1968^{2}$ : the Court required the Council of the EEC to take into account, if needed, the principle of "Community preference", which, the Court says, is a principle recognized by the Treaty and expressed, in the field of agricultural policy, at article $44 \S 2$. Thus, what was deemed to be a transitory regime was transformed into a permanent principle.

9. As a general principle of EU law, the principle of "Community preference" was also referred to, in the domain of agricultural policy, in a case decided by the Court of justice in $1976^{3}$. In that decision, the Court explained that "the general principle of Community preference" justifies a different assessment of the possibilities of disturbance (of the market of a Member State) "according to whether the products involved come from another Member State or from a third state" .

10. The Marrakech agreement signed on 15 April 1994 put an end to the "agriculture exception" (GATT rules became applicable to agricultural products). In line with this evolution, the treaty of Amsterdam (1999) repealed article 44-2, which referred to a "natural preference" between Member States. In the Court of Justice's case law, "Community preference" was scaled down to a political objective

\footnotetext{
1 On the origin of the notion, see: La notion de préférence communautaire, Rapport d'information $\mathrm{n}^{\circ} 112$ (2005-2006) by Mr J. Bizet, R. Bret, H. Haenel and R. Ries, in the name of the delegation for the EU of the French senate, delivered on Dec. 2005 (on line at: www.senat.fr/rap/r05-112/r05112_mono.html, last consulted: 28/04/2015).

2 ECJ, 13 March 1968, Beus, 5/67.

3 ECJ, 22 Jan. 1976, Balkan, 55/75.

$4 \quad \S 15$.
} 
deprived of legal force ${ }^{5}$. As such, it could not be referred to, the Court of justice considered, in order to limit the expansion of free trade ${ }^{6}$.

11. At that point, moving from free trade to movement of persons, the idea of a "Community preference" was used in the domain of economic migrations. In the Council resolution of 20 June 1994 on limitations on admission of third-country nationals to the territory of the Member States for employment ${ }^{7}$, the principle of "Community preference" was defined in these terms:

"Member States will consider requests for admission to their territories for the purpose of employment only where vacancies in a Member State cannot be filled by national and Community manpower or by non-Community manpower lawfully resident on a permanent basis in that Member State and already forming part of the Member State's regular labour market".

12. The objective of the resolution was to harmonize Member State's policies, so that admission of third-country nationals on their territories for the purpose of employment would be refused, in principle. This orientation was prompted by high levels of unemployment in Member States, which, according to the resolution, increased the need

"to bring Community employment preference properly into practice by making full use of the EURES system to improve the transparency of the labour markets and facilitate placement within the European Community".

The Council further recognized that

"the provisions of the EC Treaty and the EEA Agreement enable job vacancies to be filled as far as possible by nationals of other Member States or of Member States or of EFTA countries which are parties to the EEA Agreement".

13. The failed 2001 proposal for a directive on admission of third-country nationals for employment went further in explicitly defining the principle of the labour market test, in art. 6(1):

"This Article enshrines at Community level a general principle, which reflects the rules already in force in Member States, which require for the admission of third-country workers a thorough assessment of the domestic labour market situation. In concrete terms this means that third-country nationals may only accede to the EU labour market, if a post cannot be filled by a worker falling under either of the following categories of persons:

(a) Citizens of the Union. Citizens of applicant countries will automatically be covered by this term from the day of accession and will therefore automatically enjoy preferred treatment vis-à-vis thirdcountry nationals..."

The Commission referred to this resolution, and the principle of "Community preference" it includes, in its Green Paper of 2005 on "an EU approach to managing economic migration $»^{8}$. As all green papers, that

5 ECJ, 14 July 1994, Greece v. Council, C-353/92. See also ECJ, 10 March 2005, Spain v. Council, C342/03 (Spain had required that a measure liberalizing the trade of Tuna be suppressed, because Community goods were sufficient for the good functioning of that market).

$6 \quad$ Ibid.

$7 \quad$ Cited above.

8 Green Paper on "an EU approach to managing economic migration”, 11 Apr. 2005, COM/2004/0811 final. 
Communication was meant to target major issues, and possible options to solve them. Thus, it raised a series of question on the notion of "Community preference", its implementation, its relevance, and the need for another definition, which would extend preference beyond nationals of Member States to include, namely, non-EU nationals residing in Member States.

14. Although "Community preference", in the field of movement of persons, was only explicitly expressed in rather recent EU instruments, it was already, in essence, part of the debate and the compromise reached in 1968 concerning the regulation of free movement of workers. According to article 16 of Regulation $1612 / 68^{9}$, not only do applications of EC workers for jobs in another Member State benefit from "the same priority as that granted to national workers over nationals of non-Member States" (which corresponds to the requirement of equal treatment of workers from other Member States), but, during a period of 18 days, "vacancies shall be notified to non-Member States only if the Member State having such vacancies considers that for the occupations corresponding to such vacancies there are insufficient workers available who are nationals of the Member States". In specific cases, the regulation mentions that the priority does not prevent vacancies from being offered to workers from third countries. These exceptions include: the case when an offer is made to a named worker and is of a special nature in view of the requirement of specialist qualifications or the confidential nature of the post offered or previous occupational ties and the situation where there exist family ties, either between the employer and the worker asked for, or between the latter and a worker who has been employed regularly for at least a year in the undertaking ${ }^{10}$. Exceptions also concern vacancies for the recruitment of "homogeneous groups of seasonal workers of whom at least one named member has been offered a vacancy"; vacancies offered by employers to "workers resident in regions adjacent to either side of the frontier between a Member State and a non-Member State"; and vacancies offered "expressly to workers from non-Member States by the employer for reasons connected with the smooth running of the undertaking", where the employment services are of the opinion that such reasons are justified ${ }^{11}$. As this list of exceptions contained in the 1968 regulation indicates, it was quite clear, already at that time, that the "Community preference" principle was not at all an absolute obligation, but rather a weak rule, facing a series of important limitations. As such, it echoes the compromise that had to be reached between those in favour of "Community preference" (Italy, namely) and States opposed to that solution (France and Germany, in particular), which wanted to be free to allow employers to hire workers from outside the Community, or give preference to third-country nationals already residing on their territory ${ }^{12}$.

15. Regulation $492 / 2011^{13}$, which replaced Regulation $1612 / 68$ in 2011 , has suppressed the detailed reference to exceptional cases for admitting third-country nationals without preference being given to EU citizens. It relies on the notion of "priority" to be given to EU citizens, in order to ensure equality with nationals. According to article 14(3) of Regulation 492/2011:

"the employment services shall grant workers who are nationals of the Member States the same priority as the relevant measures grant to nationals vis-à-vis workers from third countries".

9 Regulation of the Council of 15 October 1968 on freedom of movement for workers within the Community, O.J. L 257, 19 Oct. 1968, p. 2.

$10 \quad$ Article $16(3)$.

$11 \quad$ Ibid.

12 On these historical developments, see namely : H. Verschueren, Internationale arbeidsmigratie, La Charte, 1990, p. 242 ff. and S. Goedings, Labor migration in an integrating Europe: national migration policies and the free movement of workers, 1950-1968, The Hague, SDU, 2007, p. 178ff.

Regulation of 5 April 2011 on freedom of movement for workers within the Union, O.J. L 141, 27 May 2011, p. 1 
16. According to article 17(2) of the Regulation, "Member States shall examine with the Commission all the possibilities of giving priority to nationals of Member States when filling employment vacancies in order to achieve a balance between vacancies and applications for employment within the Union". The idea of "giving priority" in this provision of the Regulation evokes a preference for EU citizens, but the text is not legally binding (as it only refers to "possibilities").

17. As far as the provisions concerning information on vacancies are concerned, the new Regulation shows that "Community preference" has become even less important than in the previous version of 1968. According to article 14 of Regulation 492/2011, the information to be forwarded to other Member States and the European Coordination Office concerns both "details of vacancies which could be filled by nationals of other Member States and details of vacancies addressed to third countries ». Thus, vacancies can be addressed to third countries at the very moment when they are addressed to other Member States, and this is no longer by exception, as in Regulation 1612/68.

18. Under the treaty on the European Economic Area (EEA, 1994) ${ }^{14}$ and the Agreement on free movement of persons concluded between the EU and Switzerland ${ }^{15}$, nationals of Member States of the EEA (Norway, Iceland and Liechtenstein) and Switzerland have a right to entry, residence and work in the EU, governed by the rules applying to EU nationals (Regulation 1612/68, now replaced by Regulation 492/2011). As a result, they benefit from the same priority as nationals of EU Member states. This is not a system of preference, for workers from the countries concerned, but the extension of the principle of equality with EU nationals, which applies to all EU citizens. Member States have no obligation, under these treaties, to make sure these workers have a priority over third-country nationals, when employment is available, on their territory.

19. As compared, "Community preference" expressed as "a priority" for workers of Member States over third-country nationals is part of the developments of the law under the agreement of 1963 establishing an Association between the European Economic Community and Turkey ${ }^{16}$. Under this agreement, freedom of movement of workers between Turkey and the EU must be progressively secured. This does not mean that Turkish workers have a right to free movement, identical to the one benefiting to EU nationals, but they progressively acquire certain rights in the host Member State, which has admitted them. The third recital in the preamble to decision $n^{\circ} 1 / 80$ of 19 September 1980 of the Council of Association on the development of the Association ${ }^{17}$ states that it is necessary, "in the social field, ... to improve the treatment accorded workers and members of their families in relation to the arrangements introduced by Decision $n^{\circ}$ 2/76 of the Association Council". As far as employment and free movement of workers, are concerned, the decision indicates that

"Subject to Article 7 on free access to employment for members of his family, a Turkish worker duly registered as belonging to the labour force of a Member State: shall be entitled in that Member State, after one year's legal employment, to the renewal of his permit to work for the same employer, if a job is available; shall be entitled in that Member State, after three years of legal employment and subject

$14 \quad$ Agreement on the EEA, signed on 2 May 1992, O.J. 3 Jan. 1994, L 1, p. 3.

Agreement between the European Community and its Member States, of the one part, and the Swiss Confederation, of the other, on the free movement of persons, 21 June 1999, O.J. 30 Apr. 2002, L 114, p. 6.

Agreement establishing an Association between the European Economic Community and Turkey, 12 Sept. 1963, concluded, approved and confirmed on behalf of the Community by Council Decision 64/732/EEC of 23 December 1963, O.J. 1973 C 113, p. 2.

Council of the European Communities, EEC-Turkey Association Agreement and Protocols and other basic texts, Office for Official Publications of the European Communities, Brussels \& Luxembourg, 1992, p. 327. 
to the priority to be given to workers of Member States of the Community ${ }^{18}$, to respond to another offer of employment, with an employer of his choice, made under normal conditions and registered with the employment services of that State, for the same occupation; shall enjoy free access in that Member State to any paid employment of his choice, after four years of legal employment"19.

20. As this language indicates, only after a period of four years employment in a Member State do Turkish workers benefit from free access to employment on the territory of that State, and only after that four year period does "Community preference" no longer condition their access to employment.

21. Precise indications on the situation of Turkish workers, as compared to nationals of Member States and third-country nationals, are articulated at article 8 of decision $1 / 80$, which states that

"1. Should it not be possible in the Community to meet an offer of employment by calling on the labour available on the employment market of the Member States and should the Member States, within the framework of their provisions laid down by law, regulation or administrative action, decide to authorize a call on workers who are not nationals of a Member State of the Community in order to meet the offer of employment, they shall endeavour in so doing to accord priority to Turkish workers.

2. The employment services of the Member State shall endeavour to fill vacant positions which they have registered and which the duly registered Community labour force has not been able to fill with Turkish workers who are registered as unemployed and legally resident in the territory of that Member State."

22. According to these provisions, Turkish workers should be preferred to other third-country nationals, when vacant positions are not filled by EU nationals, who, as for them, benefit from a priority over all other workers. However, article 8 is only programmatic: it does not oblige Member States to meet any specific obligation, but only incites them to establish a certain order of priority.

23. When considered next to the Agreement with Turkey, the specific function and legal value of "Community preference" included in recent Acts of accession is all the more visible: in these treaties, "Community preference" constitutes a compensation for maintaining restrictions to free movement of workers, for a period of transition. During this period, the Acts of accession guarantee that workers from the acceding countries are given preference over nationals of third countries, for access to the labour market of older Member States.

24. In 2004, the Act concerning the conditions of accession of 10 new Union members ${ }^{20}$ allowed older Member States to limit access to their labour markets for nationals of 8 States among the new members ${ }^{21}$. But specific provisions concerning each of the States for which free movement of workers did not immediately apply mention the principle of preference in identical terms:

“(...) the present Member States shall, during any period when national measures or those resulting from bilateral agreements are applied, give preference to workers who are nationals of the Member

\footnotetext{
$18 \quad$ Emphasis added.

19 Chapter II, Section 1, article 6 of the decision.

20 Act concerning the conditions of accession [...] and the adjustments to the Treaties on which the European Union is founded, OJ L 236, 23 Sept. 2003, p. 33.

Transitional measures only covered the Czech Republic, Estonia, Latvia, Lithuania, Hungary, Poland, Slovenia and the Slovak Republic.
} 
States over workers who are nationals of third countries as regards access to their labour market" 22 .

25. The Act adds that "in application of the principle of Community preference", migrant workers from third countries resident and working in an accession country shall not be treated more favourably than nationals of another Member State.

26. More recent accession treaties of 2005 and 2012 contain the same provisions. The principle of preference is mentioned in the protocol to the accession treaty concerning Romania and Bulgaria ${ }^{23}$, which joined the EU in 2007. Annexes to this Act concerning transitional measures use the exact same language that was used for the previous enlargement of $2004^{24}$. The same is true concerning the even more recent Act on accession of Croatia ${ }^{25}$.

27. In the Sommer case, decided in $2012^{26}$, the Court had to reconcile the principle of "Community preference" benefiting to a Bulgarian student in Austria, according to the Accession Protocol of Bulgaria, with the provisions of directive 2004/114 on the conditions of admission of third-country nationals for the purposes of studies, pupil exchange, unremunerated training or voluntary service ${ }^{27}$, which apply to third country nationals only.

28. To begin with, the Court admitted that, according to the Accession Protocol, access to the labour markets of the Member States by Bulgarian nationals was to be governed, for a transitional period, by national measures, or measures resulting from bilateral agreements, regulating Bulgarian nationals' access to the Member States' labour markets. But it also referred to the principle of preference for citizens of the European Union, included in that Act, pursuant to which Member States are required, with the exception of measures taken during the transition period, to give preference, for access to their labour markets, to nationals of the Member States over workers who are nationals of third countries. According to that provision, Bulgarian nationals must not, according to the Court, merely enjoy the same conditions of access to the labour markets of the Member States as third-country nationals, but must receive preferential treatment.

29. As a result, based on the preference clause, Bulgarian nationals have the right to be granted access to the labour market under conditions, which are not more restrictive than those set out in Directive 2004/114 for third-country nationals. Accordingly, if access to the Austrian labour market must be granted to a student who is a third-country national according to the rules laid down in Directive 2004/114, such access must be granted to a Bulgarian student under conditions which are at least as favourable and, in addition, that Bulgarian student must be given preference over a student who is a third-country national.

See annexes of the Act cited above: annex V p. 807 (Czech Republic); annex VI, p. 814 (Estonia); annex VIII p. 826 (Latvia); annex IX, p. 838 (Lithuania); annex X p. 848 (Hungary); annex XII, p. 878 (Poland); annex XIII, p. 908 (Slovenia); annex XIV, p. 17 (Slovakia).

Protocol concerning the conditions and arrangements for admission of the republic of Bulgaria and Romania to the European Union, O.J. 21 June 2005, L 157 p. 29.

See annex VI concerning Bulgaria, point 14; and annex VII point 14, concerning Romania.

Act concerning the conditions of accession of the Republic of Croatia and the adjustments to the Treaty on European Union, the Treaty on the Functioning of the European Union and the Treaty establishing the European Atomic Energy Community, O.J. L 112, 24 Apr. 2012, p. 21. Annex V, point 2 (13).

ECJ, 21 June 2012, Sommer, C-15/11.

Directive of 13 December 2004, O.J. L 375 of 23 Dec. 2004, p. 12. 
30. In that particular case, the Court of justice decided that a Bulgarian student could not be submitted to a national legislation according to which, where the fixed regional maximum number of foreign nationals employed has been exceeded, the issuing of a work permit to third-country nationals is subject, not only to the systematic examination of the situation of, and developments in, the labour market, but also to the application of additional conditions. Since directive 2004/114 precludes such systematic examination, and a fortiori precludes national measures, which go beyond that examination, such rules cannot be applied to a EU citizen benefiting from the "Community preference". 
DELSA/ELSA/WD/SEM(2016)8

\section{PART TWO: REFERENCE TO “COMMUNITY PREFERENCE” IN EU LABOUR MIGRATION POLICY DOCUMENTS}

31. The identification of references to "Community preference" will be presented chronologically, in order to identify evolutions and changes taking place in the course of the evolution of EU policy, in the field of labour migrations.

\section{1- Directive 2003/109 on the status of third country nationals who are long-term residents}

32. Although this only applies after a minimum of five years' residence in a given Member State, directive $2003 / 109^{28}$ confers on long-term residents a right to equal treatment in access to employment ${ }^{29}$. When they obtain equal treatment with nationals, under the conditions of the directive, third country nationals become a privileged category on the labour market, just as nationals of other Member States.

33. However, when long-term residents decide to migrate to another Member State, the directive allows that State to examine the situation of its labour market, and apply national procedures regarding the requirements for, respectively, filling a vacancy, or for exercising activities as an employed or selfemployed worker. For reasons of labour market policy, the text indicates

"Member States may give preference to Union citizens, to third-country nationals, when provided for by Community legislation, as well as to third country nationals who reside legally and receive unemployment benefits in the Member State concerned ${ }^{30}$."

34. It is important to note that the directive contain no obligation to respect a "Community preference", but only leaves discretion to Member States, who may want to use that principle as a reason to limit free movement of long-term residents.

35. In addition, this discretion granted to Member States is limited to twelve months, according to the second sentence of Article 21(2).

36. As compared to directive 2003/109, directive 2003/86 on the right to family reunification ${ }^{31}$, which belongs to the same generation of EU instruments concerning legal immigration, does not mention the "Community preference" at all. Article 14 (1) b) of that directive grants family members access to employment and self-employed activity in the same way as their sponsor. Member States are free to decide, according to national law, the conditions under which family members shall exercise an employed or self-employed activity ${ }^{32}$. These conditions can set a time limit, which can in no case exceed 12 months,

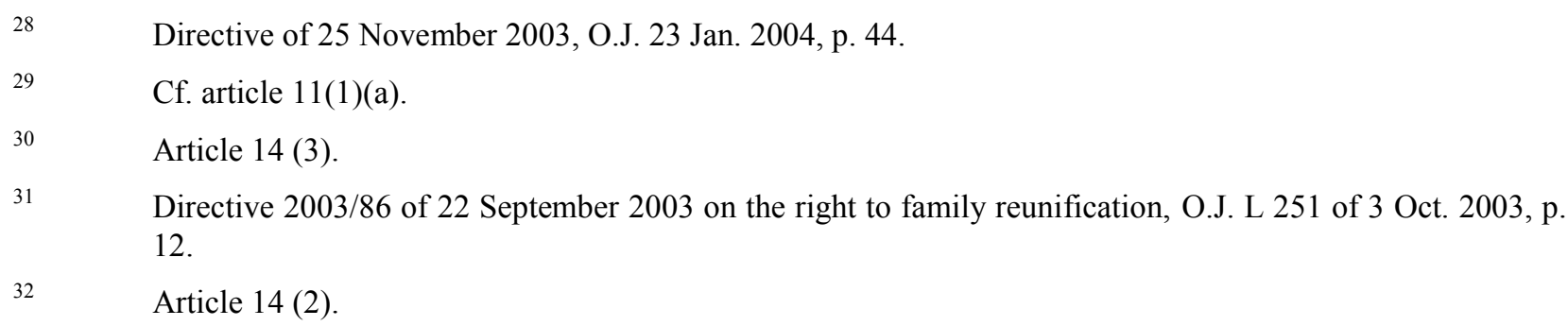


during which Member States may examine the situation of their labour market before authorising family members to exercise an employed or self-employed activity.

37. As the Commission explained in $2014^{33}$, these provisions allow for a period not exceeding 12 months, that Member States set the conditions under which family members can exercise their activity. During this period, they are allowed to restrict access to their labour market, and even perform a labour market test. But after the 12-month period, Member States are obliged to authorise family members to exercise employed or self-employed activities, provided the sponsor has such authorisation. Access to the labour becomes a right for family members, without the "Community principle" interfering.

\section{2- Directive 2009/50 on the conditions of entry and residence of third-country nationals for the purposes of highly qualified employment (Blue Card)}

38. In its preamble, the so-called "Blue Card" directive ${ }^{34}$ refers to the objectives of the Lisbon Strategy, which include fostering the mobility within the Union of highly qualified workers who are Union citizens, and, in particular, of those from the Member States which joined the EU in 2004 and $2007^{35}$. Thus, the directive requires that its implementation by Member States respects the principle of "Community preference" as expressed, in particular, in the relevant provisions of the Acts of Accession of 2003 and 2005. In the discussion of the Blue Card, members of Parliament addressed the concept of Community Preference through numerical restrictions, labour market tests and through equal treatment requirements. In addition to affirming that a labour market test could be used to restrict intra-European mobility, and that "members also ask member states not to allow Blue Cards in sectors where access to new member states' workers is still restricted". ${ }^{36}$

39. The preamble of the directive also mentions that in order to respect the principle of "Community preference" and to avoid abuses of the system, the occupational mobility of a third country highly qualified worker should be limited to the first two years of legal employment. However, this is not a binding provision of the directive. In addition, the same recital of the directive mentions that the

"occupational and geographical mobility of third-country highly qualified workers should be recognised as a primary mechanism for improving labour market efficiency, preventing skill shortages and offsetting regional imbalances" ${ }^{37}$.

40. Chapter IV of the directive, concerning rights, includes provisions on labour market access for Blue Card holders but it also affirms that these provisions

"shall be applied without prejudice to the principle of "Community preference" as expressed in the relevant provisions of the Acts of Accession of 2003 and 2005, in particular with respect to the rights of nationals of the Member States concerned to access the labour market" ${ }^{\prime 38}$.

\footnotetext{
33 Communication from the Commission to the European Parliament and the Council on guidance for application of directive 2003/86/EC on the right to family reunification, COM (2014) 210 final.

34 Directive of 25 May 2009, O.J. L 155, 18 June 2009, p. 17.

$35 \quad$ Recital 6.

36 DRAFT REPORT on the proposal for a Council directive on the conditions of entry and residence of thirdcountry nationals for the purposes of highly qualified employment2007/0228(CNS)

Recital 15.

Article 12.
} 


\section{3- Directive 2011/98 on a single application procedure for a single permit for third-country nationals to reside and work in the territory of a Member State}

41. This directive 39 only refers to "Community preference" in its preamble and it is directly linked with the accession of new Member States, submitted to a transitional period for labour migration:

"The conditions and criteria on the basis of which an application to issue, amend or renew a single permit can be rejected, or on the basis of which the single permit can be withdrawn, should be objective and should be laid down in national law including the obligation to respect the principle of Union preference as expressed in particular in the relevant provisions of the 2003 and 2005 Acts of Accession" $"$.

\section{4- Directive 2014/36 on entry and stay of third-country nationals who are seasonal workers ${ }^{41}$}

42. The preamble of directive 2014/36 mentions that the principle of preference for Union citizens as regards access to Member States' labour market "expressed in the relevant provisions of the relevant Acts of Accession" applies ${ }^{42}$.

43. Article 8 (3), concerning grounds of rejection, states that Member States may verify whether a vacancy

"could be filled by nationals of the Member State concerned or by other Union citizens, or by thirdcountry nationals lawfully residing in that Member State, in which case they may reject the application".

As this language indicates, Member states are not obliged to reject an application if local labour is available but they have the possibility to do so. Thus no principle of preference is imposed to Member states.

\section{The same article $8(3)$ mentions that it}

"shall apply without prejudice to the principle of preference for Union citizens as expressed in the relevant provisions of the relevant Acts of Accession".

Thus, under directive 2014/36, preference, for the beneficiaries of the Acts of accession, is not only a choice for Member States: it is an obligation. Priority must be given to national of new Member States over third-country nationals, even if the latter are already residing lawfully in the Member State, where seasonal workforce is needed.

45. The same system of preference applies, under article 15(3) concerning extension of stay or renewal of authorization.

\footnotetext{
39 Directive of 13 December 2011 on a single application procedure for a single permit for third-country nationals to reside and work in the territory of a Member State and on a common set of rights for thirdcountry workers legally residing in a Member State, OJ L 343, 23 Dec. 2011, p. 1.

41 Directive of 26 February 2014 on the conditions of entry and stay of third-country nationals for the purpose of employment as seasonal workers, O.J. L 94, 28 March 2014, p. 375.

42
} 


\section{5- Directive 2014/66 on the conditions of entry and residence of third-country nationals in the framework of an intra-corporate transfer ${ }^{43}$}

46. That directive mentions the principle of preference in its preamble, indicating that its application

"should be without prejudice to the principle of preference for Union citizens as regards access to Member States' labour market as expressed in the relevant provisions of the relevant Acts of Accession"

The preamble also indicates that

"unless it conflicts with the principle of preference for Union citizens as expressed in the relevant provisions of the relevant Acts of Accession, no labour market test should be required" ${ }^{45}$.

47. The meaning of the reference to the principle of preference in that recital is uneasy to grasp. The idea seems to be that submission of intra-corporate transferees to a labour market test is only possible, when EU citizens benefiting from the provisions of an Act of accession can be employed instead of a thirdcountry national, at the position concerned. At the moment this would only concern Croatian workers, since periods of transition expired, for workers of other recently acceding States.

48. Another interpretation of the recital could be that intra-corporate transferees do not, in principle, have access to the labour market (since they are only employed temporarily, and within the same group of companies). Only when these workers do, by exception, access the labour market, is it possible to apply a labour market test, in order to prefer EU citizens covered by the preference contained in an Act of accession, who would be available. This would also explain why the directive can be said, at recital 8 , to be without prejudice of the principle of preference (it only covers such situations where there is, as a rule, no "access to the labour market").

49. As far as family members of the intra-corporate transferee are concerned, Article 19 (6) states that:

“(...) without prejudice to the principle of preference for Union citizens as expressed in the relevant provisions of the relevant Acts of Accession, the family members of the intra-corporate transferee who have been granted family reunification shall be entitled to have access to employment and selfemployed activity in the territory of the Member State which issued the family member residence permit".

\section{Conclusion:}

50. Since 2009, all directives explicitly mention, although sometimes only in their preamble, the principle of "Community preference", which is considered binding on Member States. Provisions of the directives should not, as a result, allow any encroachment on this principle. This is clearly related to the Acts of accession of 2003 and 2005, which give priority to nationals of new Member States, on the labour market of older Members of the Union. As the case law of the Court of justice has shown, the legal force of the provisions on preference in these Acts does not need to be mentioned in the directives to be efficient: priority for EU citizens must be respected in all cases.

\footnotetext{
43 Directive of 15 May 2014, OJ L 157, 27 May 2014, p. 1.

44 Recital 8.

$45 \quad$ Recital 21.
} 
51. This contrasts, namely, with the directives of 2003, which either did not mention at all the principle of preference (cf. directive 2003/86) or considered that is was only an option for Member States (cf. directive 2003/109).

52. Thus, recent accessions of new Member states seem to have fostered the renewal of the "Community preference", but only in a narrow sense: preference concerns only new EU citizens, in older Member States, for a limited period of time (transition period). When transition periods end (which is the case for all of them, except the one applying to Croatian workers), so do preference mechanisms. As soon as EU "new" citizens start benefiting from the right to access the labour market, through free movement and equal treatment, their situation is to be compared (and aligned) with nationals, and no longer privileged over workers from third-country. At that point, as there is no general EU law rule limiting the freedom of Member States to allow employment of third-country national workers in jobs that could done by nationals of other Member States having free access to the EU labour market, States are under no obligation to grant preference to nationals of other Member States before admitting workers from a third country. 


\section{PART THREE: QUESTIONS RAISED BY THE PRINCIPLE OF “COMMUNITY PREFERENCE" IN EU IMMIGRATION POLICY}

\section{Is the "Community preference" a "principle" of EU law?}

53. In its decision of $1968^{46}$, the European Court of Justice referred to the principle of "Community preference", as a general principle recognised by the Treaty. This inclusion of the principle in the category of "general principles" of EU law allowed it to apply across EU law, and not only in the field on agricultural policy, where the treaty explicitly mentioned it ${ }^{47}$.

54. However, in 1994, the Court insisted that "Community preference" had no legal force but only a political value ${ }^{48}$. As a result of this evolution, some contend that it should be considered not a general principle, but a rule capable of guiding the action of EU institutions, which is inherent to the EU legal order $^{49}$. This explains why the principle could be efficiently transplanted in other fields of the common market, such as immigration policy.

55. In the field on immigration policy, the "Community preference" has become a legal rule, binding on the Union and Member States, when mentioned in Accession acts, and solely on Member States, when it is a requirement included, explicitly or implicitly, in directives.

56. As the decision of the Court in the Sommer case ${ }^{50}$ shows, "Community preference" included in Accession Protocols is indeed a binding rule that Member States must abide by, and not simply take into account, as much as possible. In that case, the Court held that during the transitional period the "Community preference" implied that Bulgarian students should have at least the same access to employment as students from a third-country, under Directive 2004/114.

57. However, the rule only has a limited scope of application, and, in most cases (this was the situation in Sommer) is only applying for a limited period of time (transition period). Thus, it cannot be considered a general principle of EU law, comparable to other general principles such as the principle of equal treatment or the principle of proportionality.

58. As a rule rather then a principle, "Community preference" must nonetheless be reconciled with other rules having the same legal value, such as, for instance, the right of third-country national long-term residents to benefit from equal treatment for access to the labour market of the State where they reside. This equal treatment principle indicates that third-country nationals who can rely on it are aligned with

\footnotetext{
$46 \quad$ ECJ, Beus, cited above.

47 On this analysis, see namely : R.-E. Papadopoulou, Principes généraux du droit et droit communautaire, Bruylant, 1996, p. 114.

ECJ, Greece v. Council, cited above.

49 R.E. Papadopoulou, op. cit. p. 117.

50

Cited above.
} 
nationals, and, as a result, with nationals of other member States too, who should not benefit from any preferential treatment, when compared with them. When third-country nationals have a right to equal treatment in the host country, based on EU legislation, "Community preference" has no more legal force, as far as these particular third-country nationals are concerned.

\section{Does "Community preference" violate a principle of non-discrimination protected by EU law?}

59. EU law recognises a general principle of equality ${ }^{51}$, and protects the right not to be discriminated against, on the ground, namely, of nationality ${ }^{52}$. Is preference to EU nationals, as far as access to work in another Member State is concerned, a violation these principles?

60. The general principle of equality, in itself, does not prohibit treating differently situations that are different, or treating similar situations differently, as long there is a legitimate justification. Consequently, the first question is whether third country nationals are in the same situation as nationals of EU member States, regarding access to employment in national labour markets. The objective of the EU integration, and the very notion of a European citizenship lead to the conclusion that their situations are different, not benefiting for social rights, but for entry on the territory, the right to residence, access to work and deportation $^{53}$. This is the condition for immigration policies limiting non-citizens' access to the labour market.

61. But this solution needs to be nuanced, when considering particular categories of third-country nationals. For long-term residents, in particular, EU legislation has created a particular status, which aim is to put this category of third country nationals in a situation equivalent to that of EU citizens, after a certain period of residence in a Member State. As mentioned before, they have become a privileged category on the labour market, when compared to other third-country nationals, since they obtain equal treatment with nationals for access to work on the territory of the State, where they have been resident for 5 years. Equal treatment implies comparison with EU citizens of other Member States in order to benefit from the same treatment. As far as their access to work is concerned, it is thus possible to contend that third-country nationals are not in a situation different from the situation of nationals of other Member States. As a result, a preference to the latter could be considered discriminatory. This solution could be based on the general principle of equality protected by EU law, and/or on article 20 (equality before the law) or 21(1) (nondiscrimination) of the Charter of fundamental rights of the European Union, which was granted the same legal value as the treaties by the Lisbon treaty (2009).

62. A preference to EU citizens, including citizens of acceding countries covered by accession agreement granting them preference, could also be considered a discrimination based on nationality violating article 18 TFUE or article 21(2) of the EU Charter of fundamental rights ${ }^{54}$.

63. However, these solutions have no precedents in the case law of the European Court of Justice. In addition, since the impact of the principles of equal treatment or non-discrimination on the situation of

\footnotetext{
$51 \quad$ See namely, ECJ, 19 Oct. 1977, Ruckdeschel, 117/76 and 16/77.

$52 \quad$ According to art. 18 TFUE: "Within the scope of application of the Treaties, and without prejudice to any special provisions contained therein, any discrimination on grounds of nationality shall be prohibited". The Charter of fundamental rights of the EU also includes a principle of equality and non-discrimination, namely on the ground of nationality (article 20 and 21).

Cf. European Commission of Human Rights, 27 June 1994, Chorfi v. Belgium, n 2/794/93 ; ECHR, 7 Aug. 1996, C. v. Belgium, n 21794/93.

Quoted above.
} 
third-country nationals constitutes a major issue of EU immigration law, controversies that are related to these solutions will not be easily swept away.

64. As far as the right to work of long term residents in another Member State is concerned, this is not an unconditional right, comparable to the right benefiting to EU citizens, since directive 2003/109 allows Member States, during the first twelve months, not only to apply a labour market test, and their national procedures regarding the requirements for filling a vacancy or exercising activities as an employed or self-employed worker, but also to give preference to other categories of non-nationals. Therefore, it remains difficult to assimilate long-term residents to EU citizens, and consider that they are in a similar situation, under EU law, during the first period of twelve months after their arrival.

65. The solution may not be the same if even more specific categories of third country nationals are considered, such as family members of either a EU citizen or a third-country national. The former have been granted a right to reside and work on the territory of Member states, to ensure family reunification. According to directive $2004 / 38^{55}$, family members of a EU citizen, whatever their nationality, when they reside in a Member State on the basis of the directive, benefit from equal treatment with nationals, namely for access to employment ${ }^{56}$. If a "Community preference" could apply to restrict their access to work, this would contradict their right to equal treatment with nationals, that is to say, their right not to be discriminated against, on the basis on nationality.

66. Family members of third-country nationals have also been granted specific rights by directive 2003/86. In particular, after a twelve months period, Member States are obliged to authorise family members to exercise employed or self-employed activities, provided the sponsor has such authorisation. Access to the labour market becomes a right for family members, without the "Community principle" being mentioned in the directive as a limit to their access to employment. Member states cannot give priority to EU citizens, since family members have been granted a right to work. In such case, thirdcountry nationals are not in a situation different from the situation of nationals of other Member States, as they can rely on a right to work on the territory, after twelve months. Applying a "Community preference" would introduce a distinction, for similar situations, which could be considered a violation of the equal treatment principle, if the distinction cannot be justified by a legitimate reason.

\section{Should the definition of "Community preference" be modified?}

67. There are political and economical arguments in favour of an extension of "Community preference" to other categories of persons than EU citizens, especially to third-country nationals already present in a Member State. Such preference to third-country manpower residing on the territory over newly arriving third-country nationals is already a national rule in several Member States.

68. The Council Resolution of 1994 on limitations on admission of third-country nationals to the territory of the Member States for employment, suggested an extension in its definition of the "Community preference":

"Member States will consider requests for admission to their territories for the purpose of employment only where vacancies in a Member State cannot be filled by national and Community

\footnotetext{
55 Directive of 29 April 2004 on the right of citizens of the Union and their family members to move and reside freely within the territory of the Member States, O.J. L 158, 30 Apr. 2004, p. 77.

Article 23 and 24 of the directive.
} 
manpower or by non-Community manpower lawfully resident on a permanent basis in that Member State and already forming part of the Member State's regular labour market" ${ }^{57}$.

69. Similarly, in its Green Paper of $2005^{58}$, the European Commission suggested that preference could be granted to third-country manpower already present in a Member State over newly arriving third country nationals. This solution was considered consistent with the directive concerning long-term residents, since these third country nationals already enjoy preference over newly arriving migrants in the Member States.

70. The Commission also suggested that "Community preference" be extended to all third-country nationals residing in a Member State different from the one where the labour shortage arises (and not only to long term residents). This seems a rational approach, looking at the economic dimension of the internal market. The obstacle lies in the political dimension of the European integration, which includes a special status for EU citizens. This tension is well illustrated in directive 2014/36 concerning seasonal workers. Article 8 (3) concerning grounds of rejection starts with allowing Member States to verify whether a vacancy "could be filled by nationals of the Member State concerned or by other Union citizens, or by third-country nationals lawfully residing in that Member State, in which case they may reject the application". But the same article also mentions that the principle of preference for Union citizens as expressed in the relevant provisions of the relevant Acts of Accession must be respected.

71. Preference could also be extended to those who have already worked for some years in the EU before returning temporarily to their own country. This would foster circulation, by allowing third-country workers to try to re-integrate in their own country knowing that they will receive more favourable treatment in terms of readmission if they later wish to come back to the EU to work. As other extensions of the notion of "Community preference" to third-country nationals, this extension seems economically rational, and legally possible. But it may face political resistance.

57 Council Resolution of 20 June 1994, OJ 19 Sept. 1996, C 274/3, emphasis added.

$58 \quad$ Cited above. 


\section{PART FOUR: INCORPORATION OF THE PRINCIPLE OF “COMMUNITY PRINCIPLE" IN NATIONAL LAW AND PRACTICE}

72. In its Green Paper of 2005 on "an EU approach to managing economic migration",59, the Commission noted, namely, that many Member States exempt from "Community preference" some types of economic migrant (intra-corporate transferees of key personnel, performing artists of international reputation, etc. $)^{60}$. That observation led to a question: what should be done to ensure that the principle of "Community preference" is applied in an effective way?

73. We will focus, in this brief examination of the issue of effective enforcement, on the French case, taken as an example. French legislation is not very demanding, when it concerns employers' obligation to look for candidates on the labour market, before requesting a work permit for a third-country national.

74. For non-EU citizens to obtain a work permit, the French labour code (article R 5221-20) requires that a labour market test is applied. This means that public authorities must take into account "the situation of the labour market in the economic sector and the geographic zone that the demand concerns" taking into account "the specificities of the job" and "the attempts made by the employer, through public placement offices, to hire a candidate, who is already on the labour market" ${ }^{\prime 61}$.

75. Before making a decision, the administration decides on the relevant labour market (departmental, regional, national or including French overseas departments) ${ }^{62}$. It takes into account statistics provided by public employment services (Pôle emploi) to assess the need for manpower from outside the relevant labour market. According to the administrative guidelines of $2011^{63}$, employers have to prove that there is no adequate candidate on the "local" labour market. And there is a presumption that this condition is fulfilled, when the job offer was published through public employment services, and was not satisfied after two months. Otherwise, the guidelines indicate that the vacancy must be advertised "adequately" for a "reasonable" period (to be interpreted as a two or three months period). This does not, obviously, give much importance to "Community preference".

\footnotetext{
$59 \quad$ Cited above.
}

$60 \quad$ Point 2.2.1.

61 «le préfet prend en compte les éléments d'appréciation suivants : $1^{\circ}$ La situation de l'emploi dans la profession et dans la zone géographique pour lesquelles la demande est formulée, compte tenu des spécificités requises pour le poste de travail considéré, et les recherches déjà accomplies par l'employeur auprès des organismes de placement concourant au service public du placement pour recruter un candidat déjà présent sur le marché du travail ».

V. Tchen, JCL Travail Traité, Fasc. 8-50, “travailleur étranger”, 15 Jan. 2015.

63

Circulaire du 31 mai 2011, Maîtrise de l'immigration professionnelle - Modalités d'application des dispositions relatives à la délivrance des autorisations de travail en vue de l'introduction de travailleurs étrangers, NOR : IOC/L/11/15117/J 
76. In addition, some third-country nationals, based on the particular relationships between France and their home country, are not submitted to a labour market test. In such case, there is no preference for EU workers that can be assessed prior to employment.

77. A recent important change in French immigration law has led to the identification of a list of activities, where manpower is needed ("métiers en tension") ${ }^{64}$ : for these jobs, no labour market test applies. For Bulgarian and Romanian workers, during the transitional period, the list included 150 types of jobs ${ }^{65}$. For Croatian workers, it includes 291 categories of jobs (until June 2015, when the transition period ends) ${ }^{66}$. Third-country nationals, as for them, only benefit from the same exemption for a more limited list of jobs (30). Specific lists apply to nationals of countries, which have concluded an Agreement with France for the management of migrations (Benin, Burkina Faso, Cape Verde, Congo, Gabon, Mauritius, Senegal and Tunisia).

78. This difference, and the preference thus given to EU citizens of two new members of the EU, has not been considered a violation of the equal treatment principle: according to the highest jurisdiction for administrative matter (Conseil d'État), EU citizens benefit from a specific regime and are, consequently, in a situation objectively different from third-country nationals, as far as access to the labour market is concerned $^{67}$.

79. In this system, if jobs are on the non-EU list (e.g., Gabon) but not on the EU transition list, "Community preference" would indeed be violated. To ensure that "Community preference" is respected, EU nationals must have access to the jobs that are open to some third-country national benefiting from a specific (and preferential) status, as a minimum.

80. As far as long-term residents are concerned, those who obtain a EU resident permit, have a right to work, without the labour market test being applied. When third-country nationals have obtained this status in another member state, and want to work in France, they are opposed a labour market test, which could allow "Community preference" to play.

81. To conclude, French legislation and practice do not appear to give much importance to "Community preference". When a labour market test applies, it does not imply strong measures to make sure that no EU citizen is able to fill the vacancy. However, EU citizens benefit from a preferential treatment in the French system. First, EU law requires that entry and residence are not conditioned by a job offer: EU citizens must be allowed to enter, in order to look for a job (and stay as long as they are actually looking for a job, and have chances to find one). Second, as opposed to third-country nationals, whose work permit is dependent on them being paid the minimum wage, EU workers have a general access to work, which cannot be conditioned by a certain level of remuneration.

82. The French case does not seem to be isolated. The UK, for instance, according to some commentators, makes a "weak application" of "Community preference" in existing policy ${ }^{68}$. In considering applicants for work permits in the UK, authorities are supposed to take into account whether appropriate

64 On this evolution, V. Tchen, loc. cit.

65 The list is included in an annex to the decree of 18 Jan. 2008.

66 The list is included in an annex to the decree of $1^{\text {st }}$ Oct. 2012.

67 CE, 23 oct. $2009, \mathrm{n}^{\circ} 314397$, Gisti: JurisData $\mathrm{n}^{\circ}$ 2009-012551.

68 See Economic Migration to the EU, House of Lords, European Union Committee, 4th report of session 2005-2006, Published by the Authority of the House of Lords London : The Stationery Office Limited, 2005, HL Paper 58, annex, Memorandum by the Joint Council for the Welfare of Immigrants (JCWI), p. 30 . 
measures have been taken to fill the vacancy with citizens of other Member States. The condition is usually considered as being met, whenever the employer has advertised the vacancy in a journal, which circulates in other Member States. This is not a very onerous requirement and is deliberately set low for practical reasons, namely that a higher standard would introduce new complexities into the administrative scheme that would generate unwanted levels of bureaucracy, costs, and delays. An administrative scheme that attempts to impose a more rigorous test of "Community preference" on job vacancies has been considered impractical and burdensome ${ }^{69}$. The argument is that, at the skilled end of the labour market, competitiveness in the recruitment of key workers would be eroded if employers were required to demonstrate that they have made more exhaustive efforts to fill vacancies on the basis of "Community preference" $"$.

\begin{tabular}{ll}
\hline 69 & Ibid. \\
70 & Ibid.
\end{tabular}


ANNEX

Table 1. APPLICABILITY OF COMMUNITY PREFERENCE TO PERMIT CATEGORIES COVERED BY EU DIRECTIVES

\begin{tabular}{|c|c|c|c|c|c|c|c|c|}
\hline Principle Applied & $\begin{array}{c}\text { Long-term } \\
\text { resident } \mathrm{TCN}\end{array}$ & $\begin{array}{c}\text { Family } \\
\text { reunification }\end{array}$ & Students & Blue Card & Single Permit & & $\begin{array}{l}\text { Seasonal } \\
\text { Workers }\end{array}$ & ICTs \\
\hline Equal Treatment & \begin{tabular}{l|l}
$\checkmark$ & 1 MS: Equal \\
& Treatment
\end{tabular} & \begin{tabular}{l|l} 
& Access to work \\
same way as \\
their sponsor \\
(Art 14(1) b). \\
Access to labour \\
market becomes \\
a right after 12 \\
months.
\end{tabular} & \begin{tabular}{l|l}
$\checkmark$ & $\begin{array}{l}\text { General rule: access } \\
\text { to the labour market }\end{array}$
\end{tabular} & $\begin{array}{l}\text { Includes provision } \\
\text { on right to labour } \\
\text { market access but } \\
\text { also affirms that it } \\
\text { should be applied } \\
\text { without prejudice to } \\
\text { CP principle. }\end{array}$ & & & & $\begin{array}{l}\text { Family members of the } \\
\text { ICT who have been } \\
\text { granted family } \\
\text { reunification shall be } \\
\text { entitled access to labour } \\
\text { market in MS1 and any } \\
\text { second MS where the } \\
\text { ICT exercises long-term } \\
\text { mobility. } \\
\text { More favourable } \\
\text { provisions are allowed. }\end{array}$ \\
\hline $\begin{array}{l}\text { Community } \\
\text { Preference (CP) }\end{array}$ & $\begin{array}{l}2 M S: \text { Community } \\
\text { preference }\end{array}$ & $\begin{array}{l}\text { CP not mentioned at } \\
\text { all. }\end{array}$ & & $\begin{array}{l}\text { Preamble requires } \\
\text { that the MS } \\
\text { respect the CP. } \\
\text { Occupational } \\
\text { mobility limited } \\
\text { first } 2 \text { years. }\end{array}$ & $\begin{array}{l}\text { Refers to CP in } \\
\text { the preamble } \\
\text { ('...can be } \\
\text { rejected') and is } \\
\text { directly linked } \\
\text { with the } \\
\text { accession of the } \\
\text { new MS. }\end{array}$ & $\checkmark$ & $\begin{array}{l}\text { CP is an } \\
\text { option } \\
\text { according to } \\
\text { Art 8.3, } \\
\text { except for } \\
\text { the (distinct) } \\
\text { principle } \\
\text { enshrined in } \\
\text { the Acts of } \\
\text { Accession. }\end{array}$ & \begin{tabular}{|l|l}
$\checkmark$ & CP mentioned in \\
preamble; \\
application of the \\
directive should be \\
without prejudice to \\
the principle of CP. \\
LMT should not be \\
required unless it \\
conflicts with CP.
\end{tabular} \\
\hline
\end{tabular}




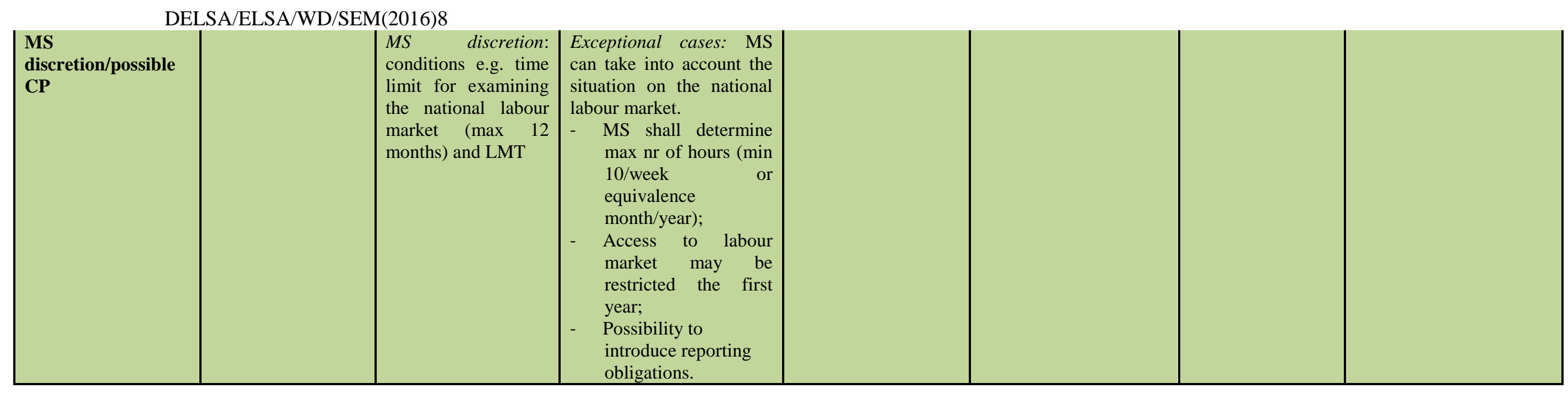

